\title{
A MILITARY HISTORY OF MODERN SOUTH AFRICA
}

\section{Ian van der Waag}

Johannesburg \& Cape Town: Jonathan Ball

2015, 388 pages

ISBN 978-1-86942-418-4; e-book ISBN 978-1-86842-372-9

Surprisingly, in a country so involved in the twentieth-century's major wars, with few exceptions, South African professional historians have for decades turned their backs on writing about the armed forces. It seemed that for the Afrikaner historians, the World Wars and the Union Defence Force were 'English' with only the Anglo-Boer War worthy of attention. The Anglophone historians, for their part, seemed to think that to show an interest in the armed forces would be to align themselves with Afrikaner nationalism and with apartheid. All too often, when professionals who ignore military studies become interested in writing their superficial knowledge is reflected in their approach to writing about military subjects.

Gradually, however, over the past two decades, a new class of professional historians has begun to emerge, trained as historians but also well-informed about matters military. In particular, in contrast to the mass of inaccurate and partisan writing by amateurs, several professionals have brought objectivity and balance to South African military history and, in particular, profound analytical thought. The prolific Ian van der Waag, writer of a great deal of good South African military history, is a leader in these approaches.

This is a gripping book - but do not expect to be aroused by the excitement of battle. This is a thought-provoking work with an academic approach. It is written with practical officers in mind, but instead of immersing the reader in the clash of arms, the author's central object is to describe the intellectual inability of South African governments and the armed forces to prepare for and to conduct war.

The scope of the work is wide-ranging, beginning with the Anglo-Boer War

Scientia Militaria, South African Journal of Military Studies, Vol 43, No. 2, 2015, pp. 199-203. doi : $10.5787 / 43-2-1131$ at the end of the nineteenth century and ending in the early twenty-first century, with a survey of the recently established South African National Defence Force. Three monumental wars and one long drawn-out 
internal war are at the centre of the work, wars that had fundamental influences on South African society. At the end of the first conflict (1902) and at the end of the most recent conflict (1989), the difficult task of integrating the former enemies into a single combined force had to be confronted.

While my bias favours the research and writing of a book such as this, inevitably, as often happens when one has high expectations, I initially feared that Van der Waag might disappoint. He has not.

The book is confined to eight readable chapters that contain descriptions of the various major wars South Africa were involved in without becoming monotonous. Van der Waag's capacity for summarising while retaining the focus of each war together with evaluations of the political and command features is excellent.

Chapter One contains a summary of the Anglo-Boer War. I must confess that I was disappointed that Ian van der Waag did not pick up my pet hypothesis about the quality of the Boer officers who, as students at the Victoria College (Stellenbosch University), had served in the VC Rifle Volunteers. Chapter Three describes the First World War, Chapter Five is a summary of the Second World War, and Chapter Seven contains a description of what the author Calls the "Hot War in Southern Africa'. But for the Anglo-Boer War, each chapter contains an evaluation from the South African side. Interesting as it would have been, it would not have been practical to examine the enemies of the time except in detail - for which there was no space. The chapters in between are, for me, absorbing descriptions and analyses of the political and military problems and the difficulties in making the right decisions in advance of the next time the armed forces would have to perform the roles for which they were intended.

In the early years of the Union and even later, it was not unusual to read rosy descriptions of the integration of Boer and British soldiers in the Union Defence Force (UDF) but without being partisan or over-emphasising differences, Van der Waag gives a more realistic image. He is also quite candid about the changes following the appointment of FC Erasmus as Minister of Defence in 1948 - a personality who, though never a soldier, as a back-bencher in Parliament had always harassed his 'Smelter' predecessors for not making the UDF 'South African' with Erasmus's own interpretation of what that meant.

There is really almost nothing in this book that I can really criticise. The book imparts insights, and the manner in which Ian van der Waag deals with the military history of modern South Africa is commendable. There are the following matters, however. 
I am sorry that the institution of the Code of Conduct for Uniformed Personnel and Civic Education (CE) - the South African version of the Bundeswehr's Innere Führung - and the reasons for its adoption and success or failure are not discussed in the final chapter. Having spent eleven years promoting CE, I would have thought the potential significance for the SANDF might seem obvious.

Then, it is always a pity that publishers insist that writers comply with time schedules. The latest version of the Defence Review would have been a fitting conclusion to this book. Since Defence Review was only recently completed and accepted by Parliament, however, it might have been dangerous for Van der Waag to engage in forecasting. Defence Review is probably the most realistic and least propagandistic defence review or White Paper ever to have been published in South Africa and it deserves the sound academic evaluation that it could have received.

Van der Waag is a very reliable researcher but, inevitably, in a work of this extent, he had to rely on numerous secondary sources and they let him down occasionally.

In particular I have doubt about the accuracy of sources he used for Endnotes 25 and 26 of Chapter Six. The appointment or reappointment from May 1948 to the Permanent Force of personnel who had refused to attest for service outside South Africa during the Second World War was not as widespread as the United Party publication or even Hans Strydom suggested. They were few enough to be identifiable and nicknamed as a group and even ridiculed by Nationalists who had served professionally outside South Africa. As for the Ossewa Brandwag, the enmity that developed between them and the Herstigte Nasionale Party - to the extent of having waylaid and attempted to assault Dr Verwoerd - also makes one wonder how they would have been accepted by Erasmus.

The discussion of the strategic doctrine of total strategy on page 250 et seq. seems a little confusing to this reviewer. It seems that the author relied largely on Chris Alden's interpretation. Simply put, 'total strategy' was General Andre Beaufre's interpretation of the Soviet Union's approach to its relations with the 'free world' in pursuit of the policy of ensuring the USSR's own security and perhaps eventually exporting communism to all countries. In many ways, total strategy was a soldier's oversimplification of relations between states. However, it did seem a systematic and interdisciplinary approach to the conduct of war. Beaufre was not the first writer to develop the theme of total strategy. Robert Strausz-Hupe and others had expounded at length on the Soviet approach in Protracted conflict. ${ }^{1}$ General Allan Fraser, while General Officer Commanding (GOC), Joint Combat Forces, had 
read Beaufre's Introduction to strategy soon after it was published in English, and realised that the absence of the study of the theory of strategy was a serious gap in South African military training. ${ }^{2}$ Accordingly, he arranged for two short special courses of lectures by academics for senior officers in 1968 and 1969. This led to formal training for staff duties courses and also the establishment of a senior staff appointment to develop strategy for the Defence Force. Fraser did not follow the academics and it is not surprising that at his farewell, he was promoted from lieutenant general to general.

It was a relief to see that Van der Waag is still historian enough not to repeat the error commonly made by writers on counter-insurgency (COIN) in South Africa, who say quite wrongly that Fraser served in Malaya during the 12-year insurgency and Gen. Magnus Malan had served with the French in Algeria. Fraser was an intellectual who devoted a great deal of time to studying counter-insurgency. His work entitled Revolutionary warfare: Basic principles of counter-insurgency was a revised edition (probably published in 1969) of his earlier work Lessons learnt from past revolutionary wars. ${ }^{3}$ Malan's interest in and knowledge of counter-insurgency were gained when he was a student at the United States Army Staff Course at Fort Leavenworth in 1968. The SADF's first acquaintance with the subject was made in 1963 when the former military attaché in France, Colonel Jan Robbertze, DSO, lectured on knowledge gained mainly during attaché visits to Algeria. In its futile attempts to persuade Western countries (and South Africans) that South Africa's problems did not stem from apartheid but simply resulted from communist attack, the National Party government tended to make itself look foolish by the way it seemed to be using the 'total onslaught' as a propaganda gimmick. Since the end of the struggle for freedom in South Africa, however, the use of what Beaufre described has been acknowledged by some African National Congress (ANC) writers. Naturally, during the struggle this could not be admitted.

Van der Waag's remark on page 254, that in 1912, the Secretary of Defence was 'constitutionally necessary' seems to be an incorrect reading of the source he used - see Endnote 42 of Chapter 7 in the book. When the author quoted in Endnote 42 spoke of "fundamental constitutional principles" he was referring to the principles implicit in the legal fiction of civil control of the armed forces by the British Parliament. The civil servants' role is to act as Parliament's watchdogs over finances to ensure the 'control' by Parliament. But 'control' was not by the authority of the civil servants as is still mistakenly believed in South Africa. This role of the civil service to act for Parliament but not on their own authority was - at least theoretically - carried over to wherever British rules extended. Before the adoption 
of the South African Constitution, 1996, there was never any constitutional requirement for a civilian secretariat in South Africa. ${ }^{4}$

The challenge to any historian is not simply to repeat what is already common coin but to come out with previously unknown or ignored information and with fresh interpretations. Ian van der Waag has, once again, succeeded very well in satisfying his readers.

Deon Fourie, University of Johannesburg

\section{Endnotes}

${ }^{1}$ Strausz-Hupe, R, Kintner, WR, Dougherty, JE, and Cottrell, AJ. Protracted conflict. New York: Harper \& Row, 1963.

${ }^{2}$ Beaufre, A. Introduction to strategy. London: Faber, 1965.

${ }^{3}$ Fraser, A. Revolutionary warfare: Basic principles of counter-insurgency. Pretoria: $4^{\text {th }}$ Survey \& Printing Regiment, n.d.

${ }^{4}$ South African Parliament, Statutes of the Republic of South Africa Constitutional Law, Constitution of the Republic of South Africa, No 108 of 1996, Section 204. Before 1996 the Secretariat was re-established by Section 2 of the Defence Amendment Act, 1995, inserted as Section 7A in the Defence Act, 1957. 